\title{
Transcatheter closure of paravalvular leaks: short- and medium-term outcomes
}

\section{Cierre transcatéter de fugas paravalvulares: resultados a corto y mediano plazo}

\author{
Piero Custodio-Sánchez * , José A. García-Montes', Juan P. Sandoval', José A. Arias-Godínez², \\ Carlos Zabal-Cerdeira1', Eduardo A. Arias ${ }^{1}$, Alejandro Solórzano-Vásquez¹, Hugo Zanella-Rodríguez², \\ Carlos Guerrero-Maya ${ }^{1}$, and Guillermo Aristizábal' \\ ${ }^{1}$ Department of Interventional Cardiology, Instituto Nacional de Cardiología Ignacio Chávez, Mexico City, Mexico; '²Department of Echocardiography, \\ Instituto Nacional de Cardiología Ignacio Chávez, Mexico City, Mexico
}

\begin{abstract}
Background: Paravalvular leak (PVL) is a frequent and important complication after surgical valvular replacement that can cause heart failure and hemolytic anemia and is associated with poor clinical outcomes. Surgical reoperation has been the standard treatment, but it is associated with high morbidity and mortality. Transcatheter closure is a therapeutic alternative. The aim of the present study is to analyze the feasibility and the short- and medium-term outcomes of the transcatheter closure of PVLs. Methods: Single-center registry of consecutive patients with post-surgical PVLs that underwent transcatheter closure, between January 2006 and December 2016. Efficacy and safety results were analyzed during the procedure and at 6-month follow-up. Results: Twenty-one PVLs (15 mitral, 5 aortic, and 1 tricuspid) were closure during 20 procedures. In the initial echocardiography, $91 \%$ of the leaks were severe. The most used device was the Amplatzer Vascular Plug II ${ }^{\circledR}$ in 10 procedures (50\%). The three-dimensional transesophageal echocardiography was used in $70 \%$ of cases. The device was successfully implanted in 95\% of cases, a regurgitation reduction $\geq 1$ grade was achieved in 95\% of the cases, and the clinical success was 79\%. Six-month survival was 100\%; however, three cases required valvular surgery (15\%). Conclusions: Transcatheter closure of PVLs is a feasible and safe procedure with high rates of technical, echocardiographic, and clinical success in the short and medium term. It is an adequate therapeutic alternative, mainly in high surgical risk patients and multiples comorbidities.
\end{abstract}

Key words: Paravalvular leak. Transcatheter closure. Results.

\section{Resumen}

Introducción: La fuga paravalvular es una complicación frecuente e importante posterior al reemplazo valvular quirúrgico que puede ocasionar insuficiencia cardiaca, anemia hemolítica y se relaciona con malos resultados clínicos. La reintervención quirúrgica ha sido el tratamiento habitual, pero se acompaña de alta morbimortalidad. El cierre transcatéter es una

Correspondence:

*Piero Custodio-Sánchez

E-mail: custodiomed@ hotmail.com
Date of reception: 25-03-2019

Date of acceptance: 23-07-2019

DOI: $10.24875 /$ ACME.M20000103
Available online: 04-09-2020 Arch Cardiol Mex (Eng). 2020;90(2):108-115 www.archivoscardiologia.com 2604-7063 / @ 2019 Instituto Nacional de Cardiología Ignacio Chávez. Published by Permanyer. This is an open access article under the CC BY-NC-ND license (http://creativecommons.org/licenses/by-nc-nd/4.0/). 
alternativa terapéutica. El objetivo del presente estudio es analizar la factibilidad y los resultados a corto y mediano plazo del cierre transcatéter de fugas paravalvulares con dispositivos oclusores. Métodos: Registro unicéntrico de una serie consecutiva de pacientes con fugas paravalvulares posquirúrgicas que fueron cerradas vía transcatéter con dispositivos oclusores, entre enero del 2006 y diciembre del 2016. Se analizaron los resultados de eficacia y seguridad durante el procedimiento y a seis meses. Resultados: Se trataron 21 fugas paravalvulares (15 mitrales, 5 aórticas y 1 tricuspídea) durante 20 procedimientos. El $91 \%$ de las fugas fue grave en la ecocardiografía inicial. El dispositivo utilizado con más frecuencia fue el Amplatzer Vascular Plug $11{ }^{\circledR}$ en 10 procedimientos (50\%). Se utilizó ecocardiografía transesofágica tridimensional en $70 \%$ de los casos. Se logró implantar el dispositivo con éxito en el $95 \%$ de los casos; se consiguió una reducción $\geq 1$ del grado de regurgitación en el 95\% de las veces y se alcanzó el éxito clínico en el 79\%. A seis meses la supervivencia fue del 100\%; sin embargo, tres casos requirieron cirugía valvular (15\%). Conclusiones: El cierre transcatéter de fugas paravalvulares es un procedimiento factible, seguro y con tasas elevadas de éxito técnico, ecocardiográfico y clínico a corto y mediano plazo. Es una alternativa terapéutica adecuada, en particular en pacientes considerados de alto riesgo quirúrgico y múltiples comorbilidades.

Palabras clave: Fuga paravalvular. Cierre transcatéter. Resultados.

\section{Introduction}

Paravalvular leak (PVL) is a relatively common and important complication, which occurs in $5-17 \%$ of surgical valve prostheses ${ }^{1-3}$ as a consequence of surgical suture failure favored by the presence of calcium, infection, tissue friability, or non-circular shape of the ring 4.5 .

Although most PVL are small and asymptomatic, $2-5 \%, 4,6,7$ have clinical relevance and can cause heart failure and hemolytic anemia and are associated with poor clinical results ${ }^{1,3,8,9}$.

Surgical re-intervention for closure of the defect or prosthetic replacement has been the classical treatment. It has shown less mortality in comparison with PVL conservative treatment ${ }^{8,10}$, but it is accompanied by high perioperative morbidity and mortality, as well as an elevated rate of residual or recurrent leaks, especially in the presence of multiple previous operations and comorbidities. In addition, in clinical practice, some patients cannot undergo the intervention due to increased surgical risk, which implies a poor prognosis, ${ }^{4,11-15}$.

Transcatheter closure is an emerging therapeutic alternative that has been shown to reduce the severity of the leak and its symptoms, with variable success rates and a low rate of complications. PVLs localization, their morphology, number, size, trajectory, as well as access, technique, and devices used have been described as factors that can influence on the results, 6 ,14,16-18. PVL have variable anatomical characteristics, which makes it very difficult for a device to fit in all cases. The specific selection of the device is based on the size, shape, and localization of the leak to completely occlude the defect without interfering with valvular function. Multiple devices that are not specifically designed for this purpose have been used, including the devices of the Amplatzer group (Abbott), which are currently the most widely used: Amplatzer Vascular Plug III (AVP III) in Europe and AVP II in USA ${ }^{19-22}$.

The purpose of this study is to analyze the feasibility and immediate and 6-month results of post-operative PLVs transcatheter closure with the use of occlusion devices in the authors' institution.

\section{Methods}

The registry of a consecutive series of patients with surgical prosthetic PVLs that were closed through transcatheter with occluder devices at Ignacio Chávez National Institute of Cardiology from Mexico, between January 2006 and December 2016, was used.

PVL was defined as the presence of jet regurgitation originating between the edge of the prosthetic ring and the surrounding native tissue observed by Doppler echocardiography. Regurgitation severity was defined according to the parameters established by the American Society of Echocardiography ${ }^{23-25}$. The transcatheter closure technique, route of access, type of implanted device, and the use or not of echocardiography during the procedure were decided at the operators' criteria. In general, for the election of the size of the device, the larger and smaller diameters of the defect were taken into account, as determined by two-dimensional or three-dimensional (3D) transesophageal echocardiography, and a device sized $\geq 1-2 \mathrm{~mm}$ than the reference diameters was used.

For all cases, baseline characteristics, echocardiogram findings, procedural details, hospital outcomes, and follow-up were collected from electronic medical records. All patients remained on clinical follow-up for 
at least 6 months, during which they underwent an echocardiographic control study. The follow-up results regarding the degree of residual leakage, change in functional class, vascular complications, device embolization, death, myocardial infarction, need for valve operation after device implantation, hemolysis, reoperation, stroke, infective endocarditis, and re-hospitalization were searched. After completing the procedure, technical success was defined as device implantation at the level of the PVL without interference with normal operation of the prosthesis or need for urgent intervention, and procedural success when, in addition to technical success, PVL reduction $\geq 1^{\circ}$ was achieved. Functional class according to the New York Heart Association (NYHA) classification was assessed at baseline and at 6 months. Clinical success at follow-up was considered when clinical improvement $\geq 1^{\circ}$ in functional class was found within the following 180 days after the closure procedure. Hemolytic anemia was defined by clinical documentation of symptoms together with laboratory tests for anemia and hemolysis ${ }^{16}$.

\section{Statistical analysis}

Qualitative variables are presented as absolute numbers and percentages, and quantitative variables as means and standard deviations. Statistical analysis was carried out with the SPSS program, version 21.0 (SPSS Inc., Chicago, Illinois, USA).

\section{Results}

During the analyzed period, 21 valvular prostheses were operated (15 mitral, 5 aortic, and 1 tricuspid) during 20 procedures. In one patient, two leaks were closed at different localizations (mitral and tricuspid) in a single procedure. Of the cases, $58 \%$ corresponded to males, average age was $45 \pm 18$ years and $50 \%$ of cases had two or more previous sternotomies. Average time from valve operation to PVL closure was 9.4 years. Demographic and clinical baseline characteristics are summarized in table 1.

The most common indications for the procedure were heart failure or hemolytic anemia in $75 \%$ of cases, and most of them (70\%) were in NYHA functional Classes II to IV. In 10 patients (50\%), multiple leaks were described (in $91 \%$ of cases they were serious) and left ventricle ejection fraction was on average $54 \pm 17 \%$ (Table 2).

Access was femoral in all individuals. As for aortic PVLs, all cases were carried out by retrograde
Table 1. Patient baseline clinical characteristics

\begin{tabular}{|c|c|}
\hline Demographic and clinical characteristics & $\mathrm{n}=20$ \\
\hline Average age & $45( \pm 18)$ \\
\hline Males & $11(58 \%)$ \\
\hline $\begin{array}{l}\text { PVL prosthetic location } \\
\text { - Mitral } \\
\text { - Aortic } \\
\text { - Tricuspid } \\
\text { Mechanical prosthesis }\end{array}$ & $\begin{array}{c}15(71 \%) \\
5(24 \%) \\
1(5 \%) \\
17(81 \%)\end{array}$ \\
\hline $\begin{array}{l}\text { History } \\
\text { - Atrial fibrillation } \\
\text { - Ischemic heart disease } \\
\text { - Hypertension } \\
\text { - Endocarditis } \\
\text { - Diabetes mellitus } \\
\text { - Previous CVD } \\
\text { - CKD (GFR < } 60 \mathrm{~mL} / \mathrm{min} \text { ) } \\
\text { - COPD } \\
\text { Pulmonary hypertension (PASP } \geq 40 \mathrm{mmHg} \text { ) } \\
\text { Average time from valve operation to } \\
\text { intervention } \\
\text { One prosthetic valve carrier } \\
\geq 2 \text { previous sternotomies } \\
\text { Baseline functional class, NYHA } \geq \mathrm{II}\end{array}$ & $\begin{array}{c}7(35 \%) \\
4(20 \%) \\
4(20 \%) \\
2(10 \%) \\
1(5 \%) \\
1(5 \%) \\
0(0 \%) \\
0(0 \%) \\
12(60 \%) \\
9.4 \text { Years }\end{array}$ \\
\hline $\begin{array}{l}\text { Indication for the procedure } \\
\text { - Heart failure } \\
\text { - Hemolytic anemia } \\
\text { - HF+ HA } \\
\text { - Echocardiographic finding }\end{array}$ & $\begin{array}{c}10(50 \%) \\
2(10 \%) \\
3(15 \%) \\
5(25 \%)\end{array}$ \\
\hline
\end{tabular}

PVL: paravalvular leak; CVD: cerebrovascular disease; CKD: chronic kidney disease, determined by a calculated creatinine clearance rate $\leq 60 \mathrm{~mL} / \mathrm{min}$; COPD: chronic obstructive pulmonary disease; PASP: pulmonary artery systolic pressure, calculated by echocardiography; NYHA: New York Heart Association classification; HF: heart failure; HA: hemolytic anemia.

approach, and in the case of mitral PVLs, in $87 \%$ of cases, an antegrade approach through a trans-septal puncture was used, while the remaining $13 \%$ were retrogradely approached from the left ventricle to the left atrium (Table 3).

The device was (technically) successfully implanted $95 \%$ of the times, only in one case was there device embolization, and $\geq 1$ degree of regurgitation reduction (procedural success) was achieved in $95 \%$ of cases. Twenty-five devices were implanted; the most widely used was AVP $\|{ }^{\circledR}$ in 13 of the closed leaks $(52 \%)$, followed by AVP $\|^{\circledR}$ in four leaks $(16 \%)$ and Patent Ductus Arteriosus Amplatzer Occluder ${ }^{\circledR}$ in other four (16\%); in addition, Atrial Septal Defect Amplatzer Occluders ${ }^{\circledR}$ were used in two leaks (8\%) and Ventricular Septal Defect Amplatzer Occluders ${ }^{\circledR}$ in two more (8\%) (Figs 1-3). In five procedures, two occluders were used due to the size and shape of the target leak or multiple leaks in the same valve. Transesophageal echocardiogram was used in $90 \%$ of procedures $(70 \%$ with $3 \mathrm{D}$ 
Table 2. Baseline echocardiographic characteristics, previous

\begin{tabular}{|c|c|}
\hline $\begin{array}{l}\text { Number of leaks present per valve } \\
- \text { One } \\
- \text { Multiple }(\geq 2)\end{array}$ & $\begin{array}{l}10(50 \%) \\
10(50 \%)\end{array}$ \\
\hline $\begin{array}{l}\text { Localization of the mitral paravalvular leak } \\
\text { ( } \mathrm{n}=17 \text { leaks) } \\
\text { - Posterior } \\
\text { - Anterior } \\
\text { - Lateral }\end{array}$ & $\begin{array}{l}9(53 \%) \\
5(29 \%) \\
3(18 \%)\end{array}$ \\
\hline $\begin{array}{l}\text { Localization of the aortic paravalvular leak } \\
\text { (n = } 7 \text { leaks) } \\
\text { - Posterior } \\
\text { - Anterior } \\
\text { - Lateral }\end{array}$ & $\begin{array}{l}3(43 \%) \\
2(29 \%) \\
2(28 \%)\end{array}$ \\
\hline $\begin{array}{l}\text { Localization of the tricuspid paravalvular leak } \\
\text { ( } n=1 \text { leak) } \\
\text { - Septal }\end{array}$ & $1(100 \%)$ \\
\hline $\begin{array}{l}\text { Paravalvular leak degree before the procedure } \\
\text { - Severe } \\
\text { - Moderate }\end{array}$ & $\begin{array}{c}19(91 \%) \\
2(9 \%)\end{array}$ \\
\hline LVEF (\%) average & $54 \% \pm 17$ \\
\hline
\end{tabular}

LVEF: left ventricle ejection fraction

technique), intracardiac echocardiogram in one case $(5 \%)$, and the procedure was guided only by fluoroscopy in one case (5\%) (Table 3).

The degree of residual leakage was zero or slight in $80 \%$ of cases and, at 6 months, $79 \%$ of clinical success was achieved. There were no vascular complications related to the procedure or cerebrovascular episodes during follow-up. At 6 months, survival was 100\%; however, three cases required valve operation (15\%); in one case, urgently due to embolization of the device and in the other two due to the appearance of hemolytic anemia. There were no cases of interference with prosthesis normal functioning (Table 4).

\section{Discussion}

Surgical reoperation is the regular procedure for the treatment of PVL; however, multiple series record a 30 day mortality of $6-22 \%$. Taramasso et al. reported $98 \%$ success for the surgical procedure in 122 patients, but with a 30 -day mortality of $11 \%$, with all cases being related to cardiac causes, which suggests that it is a highrisk intervention. These results support the need for a valid therapeutic alternative to conventional operation, especially in patients with multiple previous cardiac interventions and risk factors for higher mortality (adjunct comorbidities, chronic kidney failure, and mitral PVL)26.
Table 3. Procedure characteristics

\section{Closure technique}

\begin{tabular}{lc}
\hline Mitral leaks & $\mathrm{n}=15$ \\
- Anterograde & $13(87 \%)$ \\
- Retrograde & $2(13 \%)$ \\
\hline Aortic leaks & $\mathrm{n}=5$ \\
- Retrograde & $5(100 \%)$ \\
\hline Tricuspid leak & $\mathrm{n}=1$ \\
- Anterograde & $1(100 \%)$ \\
- Technical success & $19(95 \%)$
\end{tabular}

Type of device used ( $\mathrm{n}=25$ devices)

- Amplatzer Vascular Plug III $13(52 \%)$

- Amplatzer Vascular Plug II $4(16 \%)$

- ASD Amplatzer $2(8 \%)$

- PDA Amplatzer $\quad 4(16 \%)$

- VSD Amplatzer $2(8 \%)$

Number of devices used for each PVL

-1 occluder $\quad 15(75 \%)$

-2 occluders $\quad 5(25 \%)$

Use of echocardiography during the procedure

$-3 \mathrm{D}$ TEE $\quad 14(70 \%)$

- TEE $2(10 \%)$

- ICE $\quad 1(5 \%)$

$-\mathrm{IC}+\mathrm{TEE} \quad 2(10 \%)$

- No, only fluoroscopy $\quad 1(5 \%)$

Residual leak after the procedure

- Absent/mild

- Moderate/severe

$16(80 \%)$

$4(20 \%)$

Average fluoroscopy time 55 minutos

$\begin{array}{ll}\text { General anesthesia } & 19(95 \%)\end{array}$

Average follow-up time 26 meses

ASD: atrial septal defect; PDA: patent ductus arteriosus; VSD: ventricular septal defect; 3D TEE: three-dimensional transesophageal echocardiogram;

TEE: transesophageal echocardiogram; ICE: intra-cardiac echocardiogram;

PVL: paravalvular leak.

In the authors' series, to choose transcatheter closure, in addition to surgical risk, the number of previous sternotomies ( $50 \%$ had more than one) and patient age (45 years on average) was considered to avoid reoperation and exposure to a larger number of future re-sternotomies, since there is a progressive increase in surgical mortality with the number of reoperations.

Technical success in the series was high, similar to that of a meta-analysis of 12 non-randomized studies, where a figure of $76.5 \%$ was published ${ }^{17}$. This suggests that, despite being a technically complex procedure, experience of the centers, teamwork, and the use of appropriate imaging techniques allow obtaining good results in most cases.

Procedural success was also high, similar to that of the series published by Ruiz et al. ${ }^{6}(86 \%)$ and Sorajja et al. ${ }^{18}(89 \%)$, but unlike the series of the authors, the 


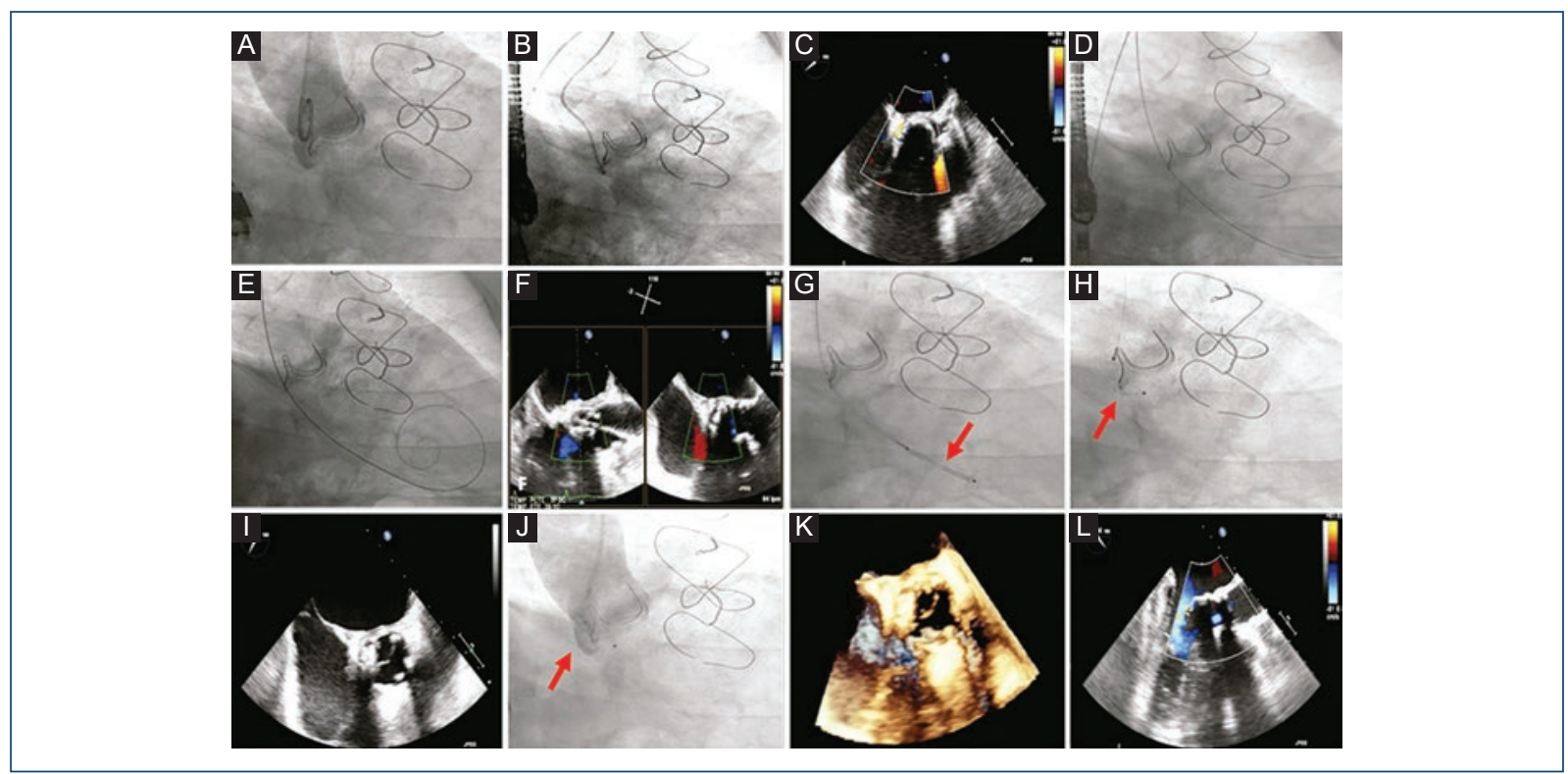

Figure 1. Transcatheter closure of an aortic paravalvular leak. Amplatzer Vascular Plug II 8 mm (red arrows). A: aortogram, severe aortic paravalvular regurgitation. B: selective leak cannulation. C: transesophageal echocardiogram (TEE), verification of the position and severity of the leak. D: retrograde crossing through the defect. E: exchange for a rigid guidewire. F: guidewire position echocardiographic verification. G: catheter advancement and occluder initial retention disk release. H: occluder final retention disc release. I: device position and valve function evaluation. J: final aortogram, slight residual regurgitation. K-L: final result with three-dimensional and two-dimensional TEE.

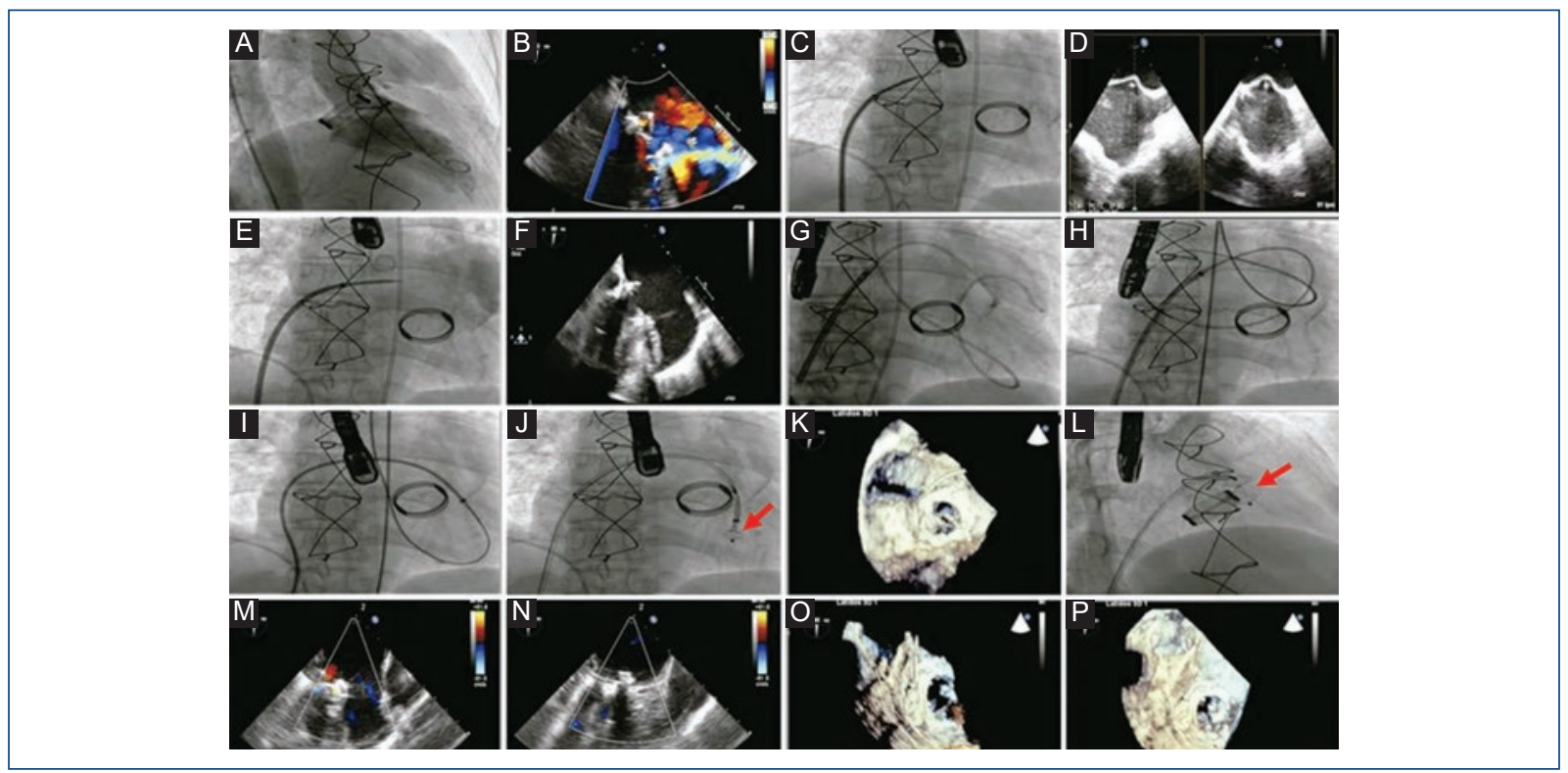

Figure 2. Transcatheter closure of a mitral paravalvular leak. Amplatzer Vascular Plug II 12/25 mm (red arrows). A: left ventriculography, severe mitral paravalvular regurgitation. B: transesophageal echocardiogram (TEE), verification of the position and severity of the leak. C: trans-septal puncture. D: TEE that guides the level of trans-septal puncture. E: angiography at the level of the left atrium. F: retrograde crossing of the guidewire from the left ventricle to the left atrium through the defect, verified by echocardiography. G-H: loop at the level of the left atrium and formation of an arteriovenous loop. I: release system anterograde advancement through the defect. J: release of occluder initial retainer disc. K: device position and valve functioning assessment. L: release of occluder final retention disc. M-P: final result by two-dimensional and three-dimensional TEE 


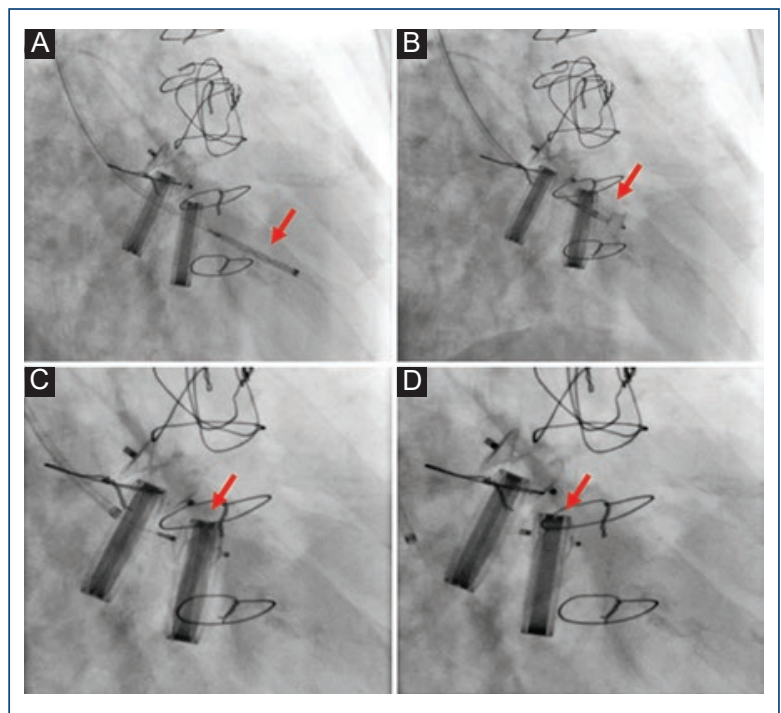

Figure 3. Transcatheter closure of tricuspid paravalvular leak. Amplatzer Vascular Plug II $8 / 4$ mm (red arrows). A: anterograde crossing of the defect from jugular access and advancement of the release system. B: release of occluder initial retaining disc. C: release of occluder final retention disk. D: final result by fluoroscopy.

Table 4. Clinical results at 6 months

\begin{tabular}{|l|c|}
\hline Final NYHA functional Class I & $17(85 \%)$ \\
\hline Vascular access complication & 0 \\
\hline Valve operation & $3(15 \%)$ \\
\hline Device embolization & $1(5 \%)$ \\
\hline New hemolytic anemia & $2(10 \%)$ \\
\hline Cerebrovascular disease & 0 \\
\hline All-cause death & 0 \\
\hline
\end{tabular}

NYHA: New York Heart Association classification.

AVP III device, main occluder used in this, was not used in those, which could be related to the high success rate found for the procedure, given that its oval morphology could better adapt to the anatomy of the defect (almost always semilunar), it comes pre-assembled, has better crossing profile, and can be introduced using smaller-caliber sheaths. In five cases (25\%), the use of two occluders was required, which shows that there is no ideal device for all cases and that, in large and irregular defects, multiple small devices can be better adjusted to the paravalvular space and avoid prosthetic dysfunction.
Up to $95 \%$ of the authors' cases had echocardiographic guidance, since it plays a crucial role during the procedure and directs the operator during different phases of the intervention, such as choosing the right place for trans-septal puncture, appropriate crossing of the guidewire through the defect, choice of the device, and immediate evaluation of the result, with severity of the leak and its size being best estimated by 3D transesophageal echocardiography. In recent years, new technology of 3D echocardiography images fusion with fluoroscopy has been described to be able to help facilitate the success of the procedure and better assess the result ${ }^{27,28}$.

In the most recently published series, clinical success at 30 days was $72 \%{ }^{29}$, similar to the authors' series, where $79 \%$ of cases improved their symptoms at 6 months. There is little evidence that compares transcatheter closure versus surgical intervention. A non-randomized comparative study, published by Wells et al., reported equivalent clinical results at 1 year between transcatheter closure and surgical intervention, with significantly less postoperative intensive care unit stay, 30-day readmission, bleeding, and perioperative morbidity. Another comparative study by Angulo-Llanos et al. noted that in-hospital mortality was significantly higher in the surgical group (30.6\% vs. $9.8 \%$ ) and that clinical improvement was significantly higher in the transcatheter group ${ }^{13,29}$. Taramasso et al. found that transcatheter closure through transapical route in highrisk patients had lower hospital mortality in comparison with surgical closure and that 12-year overall survival was $39.8 \pm 7 \%$ (although it was significantly lower in patients with more than one reoperation ${ }^{15}$ ).

Most patients $(80 \%)$ of the authors' series had no or slight residual leakage, which appears to be key to obtain a good result, since a significant relationship between the rate of cardiovascular adverse episodes, final functional class, and better long-term survival has been described ${ }^{30}$.

The procedure involves many challenges during its development and is not without complications, and constant surveillance is therefore essential. The published complication rate is low and the most common include vascular problems, urgent operation due to device embolization, interference with the prosthesis, perioperative stroke and bleeding; despite all this, death related to the procedure is uncommon ${ }^{6,19,30-32}$, which suggests that this is a safe procedure, similar to the authors' findings, where the main acute complication was embolization of a device (5\%). On the other hand, during follow-up, there was newly-occurring hemolytic anemia 
in two patients $(10 \%)$, in whom atrial and ventricular septum Amplatzer occluders were used, which forced a new valve intervention, which is significantly higher than previously reported rates with only $1.6 \%$. Consequently, the development of specific devices is necessary to overcome this important problem. In addition, end-stage heart failure has been described as the more frequent cause of these individuals' death during follow-up ${ }^{33,34}$; this indicates that transcatheter leakage closure is usually practiced at an advanced stage of heart valve disease or in the presence of multiple comorbidities.

Finally, the results support transcatheter closure of PVLs as a less invasive, effective, and safe alternative, in hands of a multidisciplinary team and after detailed planning. One limitation of this work that should be mentioned is that it was based on a single registry of a small series of patients with medium-term follow-up.

\section{Conclusions}

Transcatheter closure of PVLs is a feasible, safe procedure, with high rates of technical, echocardiographic, and clinical success in the short and medium term. It is a suitable therapeutic alternative, particularly in patients at high surgical risk or with multiple associated comorbidities. Long-term comparative studies are still needed to define transcatheter closure as the first-treatment strategy for PVLs.

\section{Conflicts of interest}

The authors declare that they have no conflicts of interest.

\section{Funding}

No sponsorship of any kind was received to carry out this article.

\section{Ethical disclosures}

Protection of people and animals. The authors declare that no experiments were performed on humans or animals for this investigation.

Confidentiality of data. The authors declare that they have followed the protocols of their work center on the publication of patient data.

Right to privacy and informed consent. The authors declare that no patient data appear in this article.

\section{References}

1. Kodali SK, Williams MR, Smith CR, Svensson LG, Webb JG, Makkar RR, et al. Two-year outcomes after transcatheter or surgical aortic-valve replacement. N Engl J Med. 2012; 366:1686-95.

2. Rihal CS, Sorajja P, Booker JD, Hagler DJ, Cabalka AK. Principles of percutaneous paravalvular leak closure. J Am Coll Cardiol Intv. 2012; 5:121-30.

3. Leon MB, Smith CR, Mack MJ, Makkar RR, Svensson LG, Kodali SK, et al. Transcatheter or surgical aortic-valve replacement intermediate-risk patients. N Engl J Med. 2016;374:1609-20.

4. Miller DL, Morris JJ, Schaff HV, Mullany CJ, Nishimura RA, Orszulak TA. Reoperation for aortic valve periprosthetic leakage: identification of patients at risk and results of operation. J Heart Valve Dis. 1995;4:160-5.

5. Rallidis LS, Moyssakis IE, Ikonomidis I, Nihoyannopoulos P. Natural history of early aortic paraprosthetic regurgitation: a five-year follow-up. Am Heart J. 1999;138:351-7.

6. Ruiz CE, Jelnin V, Kronzon I, Dudiy Y, Del Valle-Fernández R. Clinical outcomes in patients undergoing percutaneous closure of periprosthetic paravalvular leaks. J Am Coll Cardiol. 2011:58:2210-7.

7. Jindani A, Neville EM, Venn G, Williams BT. Paraprosthetic leak: a complication of cardiac valve replacement. J Cardiovasc Surg (Torino). 1991;32:503-8.

8. Genoni M, Franzen D, Vogt P, Seifert B, Jenni R, Künzli A, et al. Paravalvular leakage after mitral valve replacement: improved long-term survival with aggressive surgery? Eur J Cardio-Thorac Surg. 2000;17:14-9

9. Hein R, Wunderlich N, Robertson G, Wilson N, Sievert H. Catheter closure of paravalvular leak. Eurolntervention. 2006; 2:318-25.

10. Cho IJ, Hong GR, Lee S, Byung-Chul C, Ha JW, Chung N. Predictors of prognosis in patients with mild to moderate paravalvular leakage after mitral valve replacement. J Card Surg. 2014;29:149-154.

11. Akins CW, Bitondo JM, Hilgenberg AD, Vlahakes GJ, Madsen JC, MacGillivray TE. Early and late results of the surgical correction of cardiac prosthetic paravalvular leaks. J Heart Valve Dis. 2005;14:792-9.

12. Taramasso M, Maisano F, Denti $P$, et al. Surgical treatment of paravalvular leak: long term results in a single-center experience (up to 14 years). J Thorac Cardiovasc Surg. 2015;149:1270-5.

13. Angulo-Llanos R, Sarnago-Cebada F, Rivera AR, Elízaga Corrales J, Cuerpo G, Solis J, et al. Two-year follow up after surgical versus percutaneous paravalvular leak closure: a nonrandomized analysis. Catheter Cardiovasc Interv. 2016; 88:626-34.

14. Said SM. Paravalvular leak, the Achilles' heel of valve replacement: Will transcatheter techniques be the answer? J Thorac Cardiovasc Surg. 2015;149:1276-7.

15. Taramasso M, Maisano F, Latib A, Denti P, Guidotti A, Sticchi A, et al. Conventional surgery and transcatheter closure via surgical transapical approach for paravalvular leak repair in high-risk patients: results from a singlecentre experience. Eur Heart J Cardiovasc Imaging. 2014;15:1161-7.

16. Millan X, Skaf S, Joseph L, Ruiz C, García E, Smolka G, et al. Transcatheter reduction of paravalvular leaks: a systematic review and meta-analysis. Can J Cardiol. 2015;31:260-9.

17. Okuyama K, Jilaihawi H, Kashif M, Soni V, Matsamuto T, Yeow WL, et al. Percutaneous paravalvular leak closure for balloon-expandable transcatheter aortic valve replacement: a comparison with surgical aortic valve replacement paravalvular leak closure. J Invasive Cardiol. 2015; 27:284-90.

18. Sorajja P, Cabalka AK, Hagler DJ, Rihal CS. Percutaneous repair of paravalvular prosthetic regurgitation: acute and 30-day outcomes in 115 patients. Circ Cardiovasc Interv. 2011:4:314-21.

19. Ozkan M, Gursoy OM, Astarcioglu MA, Wunderlich N, Sievert H. Percutaneous closure of paravalvular mitral regurgitation with Vascular Plug III under the guidance of real-time three-dimensional transesophageal echocardiography. Turk Kardiyol Dern Ars. 2012;40:632-41.

20. Smolka G, Pysz P, Jasinski M. Two-stage percutaneous closure of paravalvular leak in a patient with stentless aortic bioprosthesis. Catheter Cardiovasc Interv. 2013;82:E119-23.

21. Nietlispach F, Johnson M, Moss RR, Wireline N, Gurvitch R, Tay EL, et al. Transcatheter closure of paravalvular defects using a purpose-specific occluder. JACC Cardiovasc Interv. 2010;3:759-65.

22. Moreno R, Sánchez Recalde A, López Fernández T, Moreno-Gómez I, Mesa JM, López Sendon JL. Cierre percutáneo de fugas perivalvulares mitrales en pacientes con prótesis metálica aórtica. Rev Esp Cardiol. 2012;65:768-9.

23. Lancellotti P, Tribouilloy C, Hagendorff A, Popescu BA, Edvardsen T, Pierard LA, et al. Recommendations for the echocardiographic assessment of native valvular regurgitation: an executive summary from the European Association of Cardiovascular Imaging. Eur Heart J Cardiovasc Imaging. 2013;14:611-44.

24. Zamorano J, Goncalves A, Lancellotti P, Andersen KA, González-Gómez A, Monaghan $\mathrm{M}$, et al. The use of imaging in new transcatheter interventions: an EACVI review paper. Eur Heart J Cardiovasc Imaging. 2016;17:835-835af. 
25. Zoghbi WA, Chambers JB, Dumesnil JG, Foster E, Gottdiener JS, Grayburn PA, et al. Recommendations for evaluation of prosthetic valves with echocardiography and Doppler ultrasound: a report from the American Society of Echocardiography's Guidelines and Standards Committee and the Task Force on Prosthetic Valves, developed in conjunction with the American College of Cardiology Cardiovascular Imaging Committee, Cardiac Imaging Committee of the American Heart Association, the European Association of Echocardiography, a registered branch of the European Society of Cardiology, the Japanese Society of Echocardiography and the Canadian Society of Echocardiography, endorsed by the American College of Cardiology Foundation, American Heart Association, European Association of Echocardiography, a registered branch of the European Society of Cardiology, the Japanese Society of Echocardiography, and Canadian Society of Echocardiography. J Am Soc Echocardiogr. 2009:22:975-1014.

26. Taramasso M, Maisano F, Denti P, Guidotti A, Sticchi A, Pozzoli A, et al. Surgical treatment of paravalvular leak: long-term results in a single-center experience (up to 14 years). J Thorac Cardiovasc Surg. 2015;149:1270-5.

27. Anwar AM, Nosir YF, Zainal-Abidin SK, Ajam A, Chamsi-Pasha H. Real-time three-dimensional transthoracic echocardiography in daily practice: initial experience. Cardiovasc Ultrasound. 2012;10:14.
28. Mele D, Agricola E, Dal Monte A, Ancona MB, Ferrari R. Perivalvular leak assessment and closure: role of real-time three-dimensional transesophageal echocardiography. G Ital Cardiol (Rome). 2012;13:38-46.

29. Wells JA $4^{\text {th }}$, Condado JF, Kamioka N, Dong A, Ritter A, Lerakis S, et al. Outcomes after paravalvular leak closure: transcatheter versus surgical approaches. JACC Cardiovasc Interv. 2017;10(5):500-507.

30. Shapira Y, Hirsch R, Kornowski R, Hasdai D, Assali A Vaturi M, et al. Percutaneous closure of perivalvular leaks with amplatzer occluders: feasibility, safety, and shortterm results. J Heart Valve Dis. 2007;16:305-13.

31. Kim MS, Casserly IP, García JA, Klein AJ, Salcedo EE, Carrol JD, et al. Percutaneous transcatheter closure of prosthetic mitral paravalvular leaks: are we there yet? JACC Cardiovasc Interv. 2009;2:81-90.

32. Pate GE, Al Zubaidi A, Chandavimol M, Thompson CR, Munt BI, Webb JG. Percutaneous closure of prosthetic paravalvular leaks: case series and review. Catheter Cardiovasc Interv. 2006;68:528-33.

33. Hein R, Wunderlich N, Robertson G, Wilson N, Sievert H. Catheter closure of paravalvular leak. Euro Intervention. 2006;2:318-25

34. Sorajia P, Cabalka AK, Hagler DJ, Rihal CS. Long-term follow-up of percutaneous repair of paravalvular prosthetic regurgitation. J Am Coll Cardiol. 2011;58:2218-24. 